\title{
Transient Tic Disorder
}

National Cancer Institute

\section{Source}

National Cancer Institute. Transient Tic Disorder. NCI Thesaurus. Code C116767.

A neurological disorder presenting in childhood that is characterized by motor and/or

phonic tics that occur daily or nearly daily for one to twelve months and are not attributed to an identifiable cause. 